\title{
A NOTE ON SUNGSANG VILLAGE AT THE ESTUARY OF THE MUSI RIVER IN SOUTHEASTERN SUMATRA: \\ A RECONSIDERATION OF THE HISTORICAL GEOGRAPHY \\ OF THE PALEMBANG REGION
}

\author{
O. W. Wolters
}

On July 4, 1978, I had the opportunity of visiting the estuarine village of Sungsang. 1 My companions and I went there to search for surface sherds. We left with more than we had expected, for we were able to recover the historical geography of the lower reaches of the Musi river more accurately than I had done when I wrote an article on the subject for Indonesia in 1975.2 In this note I shall revise my earlier understanding of Chinese texts of the Ming period and shall invoke geological evidence in support of my revised interpretation of their contents. I shall suggest that, contrary to my suggestion in 1975, the present estuary and shipping fairway, connecting Palembang with the sea, have not substantialiy changed since the fourteenth century.

Sungsang village is less than five miles from where the Musi river debouches into the Bangka Strait and is approximately fifty miles downstream from the modern city of Palembang. ${ }^{3}$ The journey took about two hours in small craft powered by outboard motors. 4 Sungsang is off to port when one travels downstream, and we spotted it soon after the Menumbing range of hills, pale in the distance, came into sight at the northwestern end of Bangka Island. ${ }^{5}$ The spacious view out to sea is

${ }^{I}$ I accompanied Dra. Satyawati Suleiman, of the National Research Centre of Archaeology, Indonesia, and her colleagues, Dra. Satari and Dra. Rumbi Mulia. Dr. M. E. Osborne, Mr. E. P. Edwards McKinnon, and Dr. A. C. Milner were members of our party. I am grateful to my companions for their observations during and after our visit. I also wish to thank the following for their comments on the first draft of this essay: Dr. J. V. G. Mills, Professor Stanley J. O'Connor, Professor John M. Echols, Dr. William J. O'Malley, and Dr. John N. Miksic.

20. W. Wolters, "Landfall on the Palembang Coast in Medieval Times," Indonesia, 20 (October 1976), pp. 1-57.

${ }^{3}$ These distances are based on the Eastern Archipezago Pizot, 4 (London: Hydrographic Office of Great Britain, 1890- ), pp. 64 and 66. The 1966 edition of Volume 4 does not mention the village of Sungsang.

${ }^{4}$ According to van Sevenhoven, local craft manned by oarsmen could make the journey from Palembang to the Sungsang estuary in a few hours when the tide was ebbing; J. J. van Sevenhoven, "Beschrijving van de hoofdplaats van Palembang," Verhandelingen van het Bataviaasch Genootschap van Kunsten en Wetenschappen, 9 (1823), p. 50.

${ }^{5}$ An anonymous early nineteenth century Dutch source states that Muntok, on Bangka's northwestern shore, was about eight hours away from the estuary; De Heldhaftige Bevrediging van Palembang (Rotterdam: Arbon en Krap, 1822), p. 12. 
breath-taking. Here was one of the busiest shipping lanes in early Asian history.

Sungsang village is on the estuary's western shore and faces upstream at the edge of a large bay; it also extends along the coast towards the sea.6 The main street is built on tall wooden poles over the tidal waters, but a substantial stretch of 1 and 1 ies behind the street to the north. Sungsang was one meter above sea-level in 1975.7 our visit was too brief to enable us to go far inland towards the northern seashore, but we were told that a rice cultivation project was under way. The expanse of firm land is probably quite considerable. 8

We visited Sungsang because Palembang motorboat skippers had told us that we should go there if we wanted to find sherds, and, indeed, we saw numerous ones on the surface not far behind the main street. 9 The sherds were chiefly nineteenth century Dutch and Chinese ware, but Mr. McKinnon identified a few pieces as earlier Chinese products of the Wan-Ii reign-period (1572-1620) and also of the Sawankhalok kilns of northern Thailand. 10 Mr. James Watt, of the Chinese University of Hong Kong, later told me that specimens of Wan-1i ceramics could be expected to reach Southeast Asia not long after their production and could also be expected to be found alongside Sawankhalok sherds.11

The ceramic evidence suggests that Sungsang was an inhabited settlement as early as about 1600 , which would not be remarkable; the settlement undoubtedly existed in 1681 , when it is mentioned in an agreement reached between the Vereenigde Dost-Indische Compagnie and the Sultan of Palembang. I2 But our visit to Sungsang enabled us to interpret other documentary evidence that indicates that the settlement existed at least two centuries earlier than 1600. I shall discuss this evidence because I wish to correct my misunderstanding of its signifi-

${ }^{6}$ According to Von de Wall's MaZeisch-NederZandsch Woordenboek, "Sungsang" means "tegen den draad in," or "against the grain"; H. von de Wall (uitg. door H. N. van der Tuuk), Batavia, 1880, vol. 2, p. 244. "Sungsang" can al so mean "tegen de stroom op," or "against the stream"; H. D. van Pernis, Woordenboek Bahasa Indonesia--Nederrands (Groningen: Wolters, 1950), p. 259.

${ }^{7}$ Sumatera Selatan DaZam Angka (Palembang: Pemda. Prop. Sum. Sel., 1976), p. 9.

${ }^{8}$ In the middle of the nineteenth century there were five hundred households; "Schetsen over Palembang," Tijdschrift voor Neëriand's Indië, 8, 3 (1846), p. 313. In 1930 the population was 6,546. Volkstelling 1930, 4 (Landsdrukkerij: Departement van Economische Zaken, 1935), p. 135, Table 2.

${ }^{9} \mathrm{Dr}$. Osborne, whose boat arrived at Sungsang before mine, was able to visit more areas than $I$ did, and he gained the impression of widespread sherd deposits behind the main street along the waterfront.

${ }^{10}$ Sawankhalok ware is usually reckoned to be from the fourteenth to the sixteenth century. The sherds we collected are now in Jakarta.

lloral communication in July 1978. I am grateful to Mr. Watt for discussing the subject with me.

12 Dagh-Register, ed. F. de Haan (Batavia, 1919), for the year 1681, p. 485. "Sungsang" is written "Sousang" in the agreement but appears as "Soensang" in the index to this volume. 
cance when I wrote my article in Indonesia in 1975 on the historical geography of the Palembang area.13 I submit my revised views for the judgment of geologists, to whom the analysis of the changing morpho1ogy of the Musi river basin is as much a challenge as it is to historians.

During the first decades of the fifteenth century, the Ming fleets, often under Chêng Ho's command, sailed frequently in Indonesian waters and visited the Palembang coast no less than four times. ${ }^{14}$ The accumulated navigational notations were recorded, together with additional maritime experiences, in sailing directions known as the Shun-fêng hsiang-sung, written about 1620.15 The preface to the compilation mentions how, during the expeditions in Chêng Ho's day, charts of "the direction of the compass-needle and the guiding stars" were "compared and corrected." I6

An immense body of geographical knowledge became available as the result of the activities of the Ming fleet in the early fifteenth century, and the seamen's handling of this knowledge would have been similar to the handling of records by the compilers of the chapters on foreign countries in the Chinese imperial histories. The historians rarely discarded earlier information, and the effect is that their work reads less as revised and critical statements than as a sequence of raw entries of different vintages that were extracted from official files. Those who compiled navigational data would have behaved in a similarly conservative manner, introducing new material only when there were gaps in the older sources but never eliminating older material unless such material was palpably obsolete; after all, sailing directions were intended to be of practical value in helping pilots reach ports where trading opportunities existed. For example, the shun-fêng hsiang-sung incorporates later information about the shipping routes to and from the port that served Aceh, which had not existed at the time of the great Ming expeditions in the fifteenth century when Lamri and Pasai were the important centers on the northern coast of Sumatra.

On the other hand, the continuing survival in the sailing directions of the expeditions navigational experience off the Palembang coast is revealed in two ways. In the first place, there are no references to routes to the ports of the Riau-Johore state, where the former rulers of Malacca had their base after Malacca fell to the Portuguese in 1511. Malacca is always the major terminus on the Malay Peninsula. Second, the sailing directions do not mention Jambi, and I attribute this circumstance to Jambi's temporary decline as an important trading center after the Javanese attack of 1377.17 Thus, the sailing directions for western Indonesian waters seem to reflect the political situation in Chêng Ho's day. This part of the shun-fêng

13 Wolters, "Landfa11 on the Palembang Coast."

$1{ }^{4} \mathrm{~J}$. V. G. Mills (translator, editor, and annotator), Ma Huan: Ying-yai ShêngIan (Cambridge: Cambridge University Press, for the Hakluyt Society, 1970), pp. 10-19.

15 Mills, Ma Huan, p. $355 . \quad{ }^{16}$ Ibid., p. 240.

170. W. Wolters, The Fall of Srivijaya in Malay History (Ithaca: Cornell University Press, 1970), ch. 5. Also see Wolters, "Landfall on the Palembang Coast," pp. 33-35. 
hsiang-sung freezes, I believe, the ample navigational experience of the early Ming pilots. In 1407 a naval battle was fought off the Palembang coast against the pirate Ch'ên Tsui-i,18 and in 1432 Chêng Ho was in the same area from July 24 to July $27 ;^{19}$ he was sailing from eastern Java to Malacca and would have taken the route through the Bangka Strait that is plotted in the sailing directions. The navigational problem encountered when his pilots were approaching Palembang was, as we shall see, sufficiently complicated to need careful recording and would not have been revised.

The pilots' problem is succinctly described in the Shun-fêng hsiang-sung's directions for the voyage from an island off the Vietnamese coast 20 to Banten in western Java ${ }^{21}$ via Palembang, known as the "Old Channel" (嚄港 ). Pilots were advised first to identify the middle hill in the Menumbing range behind Muntok town on northwestern Bangka:

When the ship's stern is set on Niu-t'ui-ch'in [the central hill in the Menumbing range], you make and enter the old Channel [in order to proceed upriver to the trading center also known as the "old Channel"]. The strip of 1 and [facing Bangka] has three channels. The middle one is the correct passage. There is a small island in it. ${ }^{22}$

On their return journey from Banten to the Vietnamese coast the pilots were told to spot the same island when they were reaching the northern end of the Bangka Strait:

The ship makes for the middle of the [Bangka] Strait. One sees Niut'ui-ch'in hill. A strip of land is off to port. In the middle there is an island. Here is the estuary of the old Channe1.23

A further reference to the estuary is made in the directions for the voyage from Banten via the old Channel to Pulau Tioman off the east coast of the Malay Peninsula:

The left side [or Sumatran side of the Bangka Strait] is shallow. The right side [the Bangka Strait] is deep and ships can proceed along it. Take a sounding for 4-5 fathoms. Follow the land for ten watches. Take a sounding for 5-6 fathoms and then one sees the estuary of the channel off to port. There is an island that comes up off to starboard [when the ships enter the estuary], and this is the old Channe1.24

18 Wolters, Fall of Sirvijoya, p. 74. 19Mills, Ma Huan, pp. 15-17.

${ }^{20}$ For the approximate location of this island, known to the Chinese as Ch'ih$k^{\prime}$ an, see ibid., p. 275.

${ }^{21}$ I follow Mills in rendering Shun-t' $a$ as Banten. Ibid., p. 217.

${ }^{22}$ Shun-fêng hsiang-sung, c. 1620 (Bodleian Library, Oxford, Laud MS Or. 145), p. 34b. I wish to thank Dr. Mills for giving me a xeroxed copy of the manuscript.

${ }^{23}$ Ibid., p. 35b. I translate 州 as "island" and not as "settlement" whenever the word appears in the passages cited below.

${ }^{24}$ Ibid., p. $27 \mathrm{~b}$. 


\section{BANGKA from Sungsang \\ July 1978}

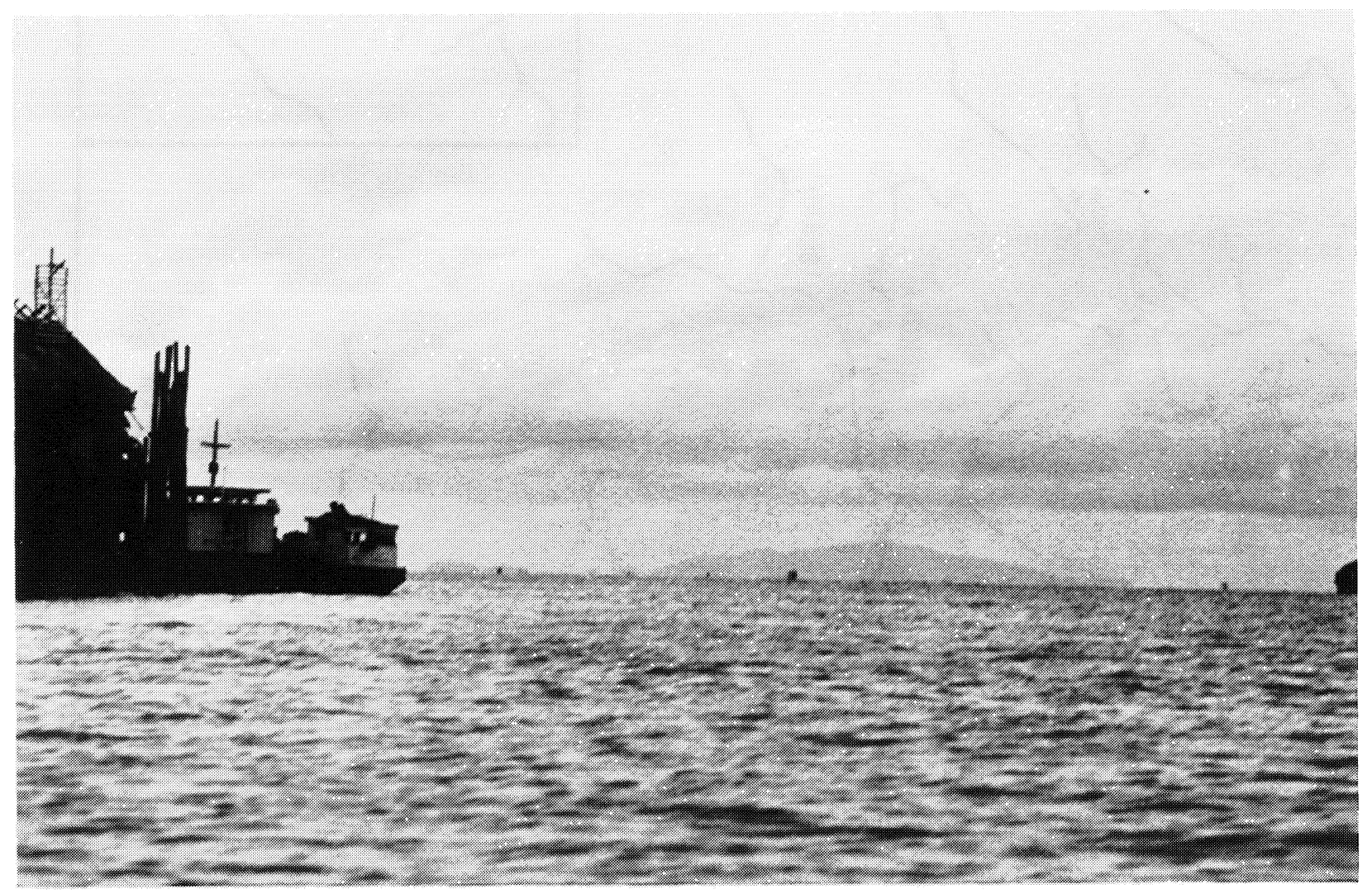

Photo: Edwards E. McKinnon 


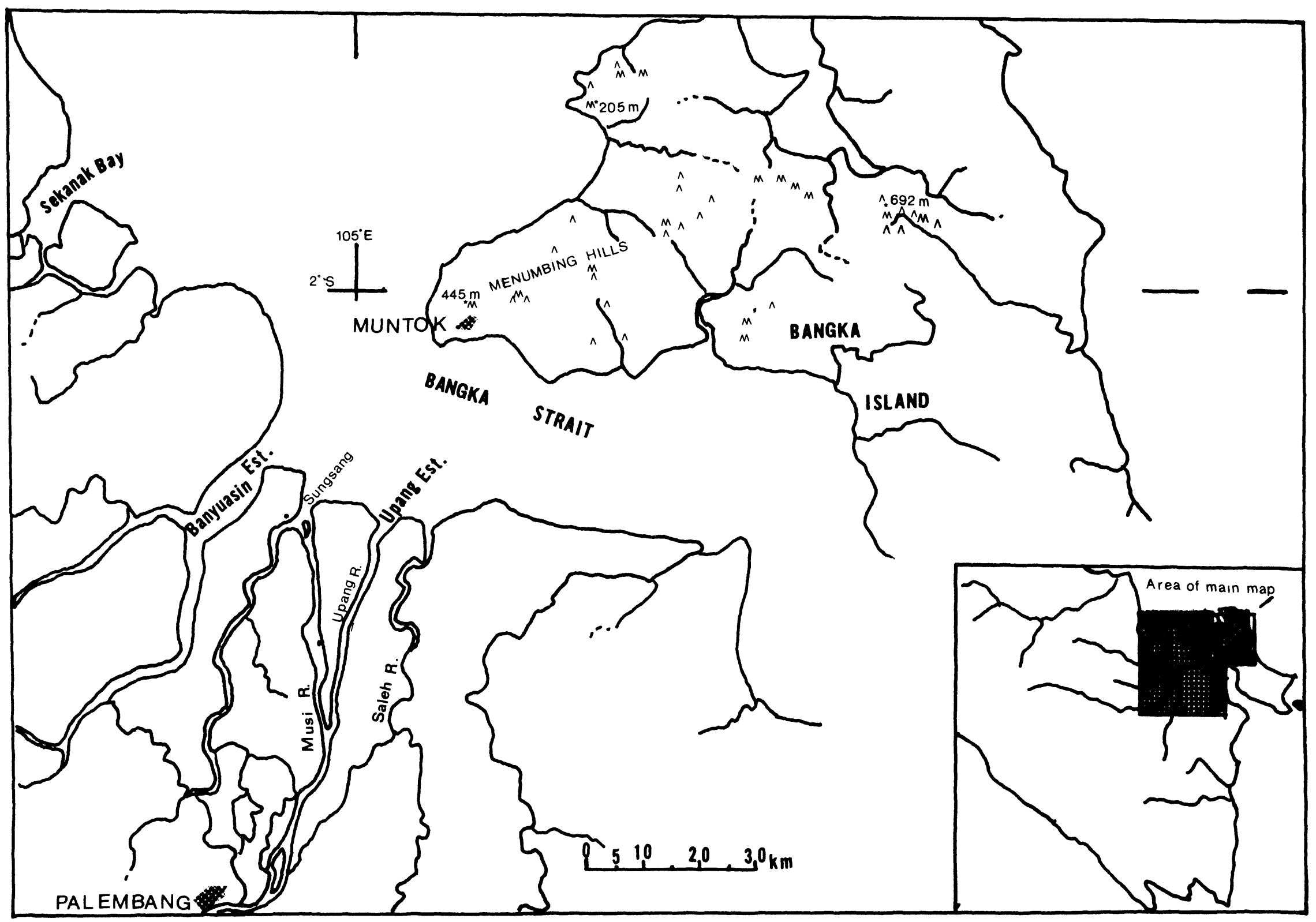

BANGKA STRAIT 
The Shun-fêng hsiang-sung's 1 ist of natural features observed when sailing from Java to Malacca distinguishes the correct estuary in similar terms:

The old Channel estuary. There are no hills on the strip of land. In the estuary there is an island. The island is off to starboard [in the estuary]. ${ }^{25}$

The island was so important an identification mark that the directions for the voyage from Malacca to the Old Channel state:

In the middie [of the uic cilannei estuary] there is añ islanu.

There is the correct passage, and it must be correctly recognized as such. 26

The sailing directions provide yet a further means of identifying the estuarine island. In the section dealing with the final stage of the voyage from Tuban in eastern Java via the Bangka Strait, pilots were advised:

At the end of a strip of land [the Sumatran coast] a point juts out off to port. Steer $N W$ by $W$ for ten watches and make the correct passage to the 01d Channel. In the passage there is an island. When you look around, there are inhabitants. That is it. 27

The Chinese pilots' problem was always to be able to distinguish the correct estuary from the two other and nearby estuaries on the same coast. Once they had identified the middle estuary, their ships had no further difficulty in proceeding upstream to their destination in the neighborhood of Palembang about fifty miles inland. The Shunfêng hsiang-sung has therefore nothing to say about the voyage up and down the Musi river. 28

My earlier interpretation of these excerpts must now be revised. The inhabited island was not the palembang-bound ships' terminus but only the indispensable landmark that immediately became visible off to starboard when they entered the estuary with Bangka Island off to stern. The pilots knew as soon as they had seen the island that they were on the correct course. Sungsang's location as we beheld it at the Musi estuary matches the details in the Chinese sailing directions so exactly that Sungsang can be identified with assurance as the landmark that Chinese pilots recognized as soon as they began to leave the Bangka Strait. Sungsang village, as far as 1iterary evidence is concerned, existed at least as early as 1400 , and it would not be surprising if it occupied more or less the same site that it occupies today. The village faces inland and is protected by its hinterland during the western monsoon from November to April and during the eastern monsoon from May to October. ${ }^{29}$

${ }^{25}$ Ibid., p. 16b. $\quad{ }^{26}$ Ibid., p. 54a. $\quad{ }^{27}$ Ibid., p. $39 \mathrm{~b}$.

${ }^{28}$ Sailing directions are provided for the return voyage down the Musi only when ships were leaving the estuary; ibid., pp. 39a and 54a. No directions are provided for the voyage upstream from the island.

${ }^{29}$ The east monsoon is more moderate than the west monsoon, when strong winds and violently pelting rain can be expected from December to February; J. C. M. 


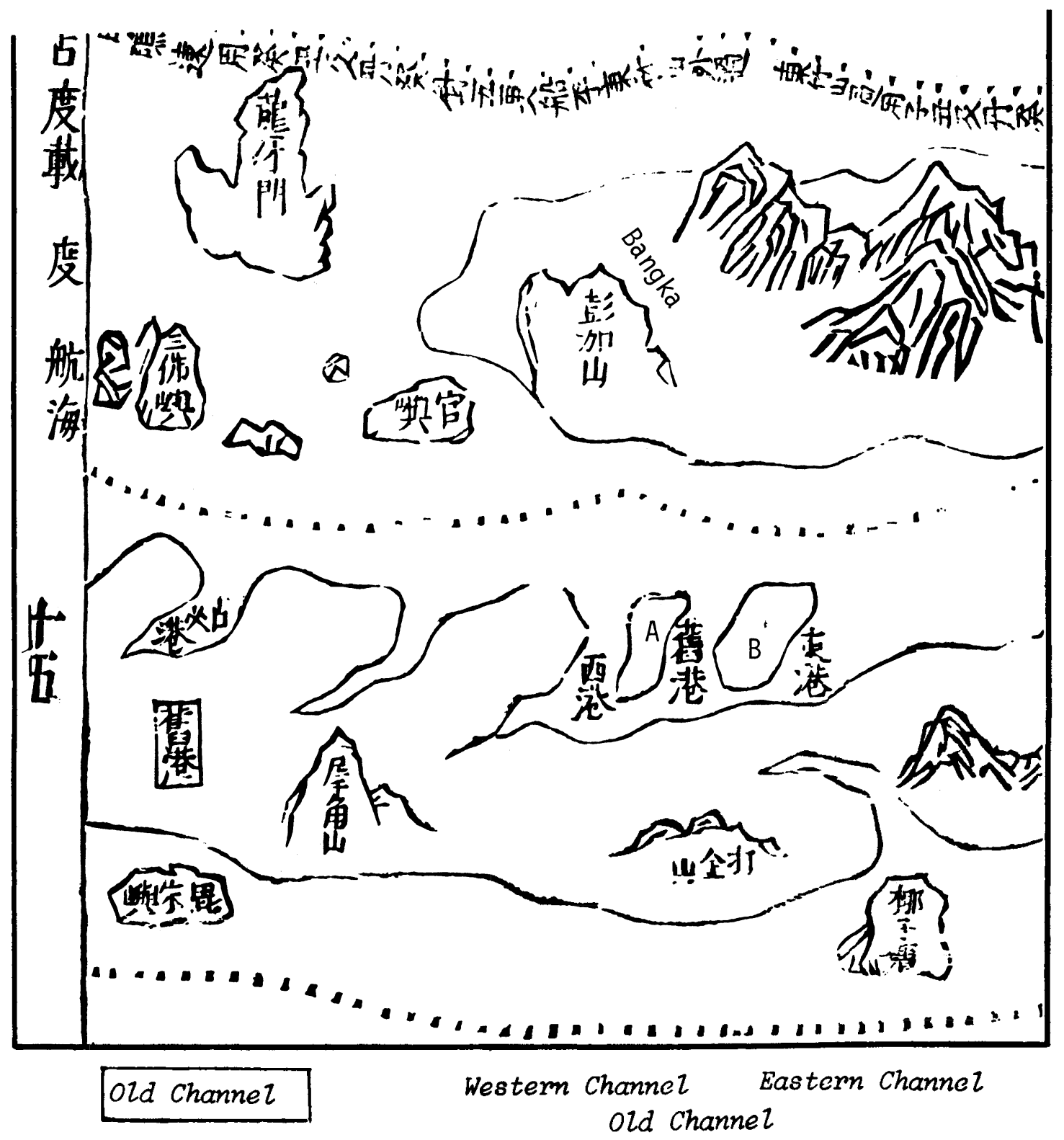

Mao K'un Map 
The sailing directions, as I have now interpreted them, help to clarify the details of the Palembang coast in the famous Mao K'un map, another product of the Ming voyages in the early fifteenth century. Dr. Mills considers the map to have been completed by 1422.30

The important details on the map are its three estuaries, and the midale one is marked "Old Channel." The map shows two large islands [A and B] facing the northwestern end of Bangka island, but we must bear in mind that the Chinese pilots were not explorers and that their cartographers were not interested in mapping waterways ignored by Chinese merchant ships. Those who drew the Mao $\mathrm{K}^{\prime}$ un map, as well as those who compiled the sailing directions, were content to suppose that Sungsang was an "island"; ${ }^{3}$ they were, however, only concerned with that part of it visible from ships sailing up and down the main Musi channe1. The essential details on the map concern the three estuaries, known as the "eastern channel," the "Old Channe1," and the "western channel" respectively. The "Old Channel" is the middle channel, and it corresponds with what the shun-feng hsiang-sung calls "the middle channe1" and "the correct passage." I am sure that Dr. Mills is justified in identifying the Mao K'un map's "western channel" with the Banyuasin river. 32 The next estuary or gulf is unnamed on the map; it may represent what was once a large inlet in the neighborhood of present-day Sekanak Bay. A French map, dated 1708, suggests this possibility. 33

The most extensive revision of my earlier interpretation of the Mao K'un map concerns the "eastern channe1." I am now convinced that this channel was never used for access to the Palembang area in the fourteenth and fifteenth centuries. Dr. Mills had identified it with the Saleh river, but I believe that it is the Upang river, which joins the Musi not quite halfway up to Palembang. ${ }^{4} 4$ The Upang estuary is closer to that of the Musi than is the Saleh estuary, and would therefore have caused trouble for the incautious pilot. The shun-fêng hsiang-sung warns that the "eastern channel's" estuary was muddy and

Radermacher (1741-1783), "Beschryving van het Eiland Sumatra in zo verre het zelve tot nog toe bekend is," Verhandelingen van het Bataviaasch Genootschap der Kunsten en Weetenschappen, 3 (Batavia, 1781), p. 136. According to de Sturler, when strong winds blew during the east monsoon and the Musi passage was obstructed, the Banyuasin river further north was sometimes used. De Sturler also says that the east monsoon months were when the Sungsang people fished along the coast; W. L. de Sturler, Proeve Eener Beschrijuing van het liekiad van PaZembang (Groningen: Oomrens, 1843), pp. 43, 154.

30Mi11s, Ma Huan, pp. 241-42. The Mao $\mathrm{K}^{\mathrm{t}} \mathrm{un}$ map is reproduced on page 40 of this article and is the version edited by Ugai Nobuyuki. Extant versions of the map are mentioned in note 52 in my "Landfall on the Palembang Coast."

${ }^{31} \mathrm{Mr}$. McKinnon suggests that Sungsang may have been an island in the fifteenth century. Small channels may still join the Banyuasin and Telang rivers. De Sturler's information about the Banyuasin in note 29 above supports Mr. McKinnon's suggestion.

${ }^{32}$ Mil1s, Ma Huan, p. 194.

${ }^{33}$ See Map 10 on page 20 in Wolters, "Landfall on the Palembang Coast." The map is described in note 61 on page 21 of that article.

${ }^{34}$ Mills, Ma Huan, p. 224. In a letter dated December 5, 1978, Dr. Mills told me that he accepted the Upang river identification. 
the water shallow. ${ }^{35}$ De Sturler, writing in the middle of the nineteenth century, says of the Upang river that it was broad and deep, but that its estuary had a thick bank and brigs could not sail in 1 and. 36

The Mao $K^{\prime}$ un map, as far as the Palembang area is concerned, was intended to be no more than a map of estuaries and should not be searched for the precise location of the upriver trading settlement. The cartographic details do not supply any information about the settlement unless the western "Old Channe1," enclosed in a rectangle, is the cartographers' somewhat casual device for including the upriver port on the map. 37 The Ming naval commanders in the early decades of the fifteenth century knew that the port was administered by overseas Chinese, and the cartographers may have wished in this way to indicate that a seat of government existed in the area. Chinese navigators, however, knew that their problem was the correct identification of the channel that connected the port with the sea, and the Mao $K$ ' un map and the sailing directions address themselves to the problem.

I have now revised my earlier article very extensively. Nevertheless, I remain convinced that the correct translation of the term kang (港) in its Palembang context is "channe1" and not "anchorage" or "harbor." From the point of view of Chinese merchants, everything depended on identifying the entrance to the "channel" that led to their upriver destination. The long channel shaped their thinking about the area, and Sungsang on the channel's estuary was the landmark that enabled them to reach the channel's port. Not surprisingly, the port became known to them as the "Old Channel" in the sense that it was "the port of the old Channel." The nickname embodies the navigational experience of Chinese merchants who were accustomed to visiting the Palembang region long before the fifteenth century and were probably doing so soon after Chinese ships began to sail into more distant Asian waters in the twelfth century. The channel and its upstream entrepôt became affectionately known as "old" simply because the Chinese had known the area long before Wang Ta-yuan, recording Chinese merchants' knowledge in the first half of the fourteenth century, used the expression "O1d Channe1."38

The expression "01d Channel," because it reflects the antiquity of the channel from the estuary to the Palembang center, may have geological significance, and I shall make some further observations, based on our visit to sungsang, for criticism by geologists. The historical geography of the Musi basin has interested geologists as well as historians ever since obdeyn in 1941-43 published his startiing reconstruc-

${ }^{35}$ Shtu-fêng hsiang-sung, p. $15 \mathrm{~b}$.

${ }^{36}$ De Sturler, Proeve eener Beschrijuing, p. 43.

${ }^{37}$ This is Dr. Mills' interpretation of the western "Old Channel"; Mills, Ma Huan, p. 284.

${ }^{38}$ Wang Ta-yüan, Tao-i chih-lüeh chico-chu (Peiping: Wên tien ko shu chuan, Kuohsüeh wên $\left.k^{\prime} u 26,1936\right)$, p. 84. The nickname "old Channel" does not mean, of course, that the name "Palembang" was unknown to the Chinese. Palembang is specifically mentioned by Chao Ju-kua, writing in the early thirteenth century; F. Hirth and W. W. Rockhill (translators and annotators), Chau Ju-kua (St. Petersburg: Imperial Academy of Sciences, 1911), p. 62 . 
tion of the ancient shape of the east coast of Sumatra. ${ }^{9}$ Dr. Miksic has recently discussed the complex geomorphic situation in the Straits of Malacca region as it has now become known to scientists. In his words, "the local depth of the ocean-bed, river-course changes, nearshore ocean currents and wave patterns, and human activity all may have acted at various times and in various ways to alter the coastline. 140

Sungsang's recorded history seems to contribute to a better understanding of the involved geological processes in the lower Musi basin because it supports by extended documentation the conclusions reached by Drs. Chambers and Sobur as a result of their recent research. 41 In 1975 these geologists observed that Sungsang was at its present location at least two hundred years ago, even though the village is still only nine kilometers from the open sea. I have now suggested that its location can be reasonably pushed further back by at least three centuries.

The geological research undertaken in 1975 has implications for Palembang's historians, and I shall summarize it. Drs. Chambers and Sobur believed that upstream riverine sedimentation did not account for the expansion of tidal swamps on the Sumatran coast inside the Bangka Strait. 42 They suggested that the coastal accretion in question was caused by seaborne sedimentation as the result of a long-shore drift southwards from the Musi-Banyuasin drainage system. The mud from the north was deposited south of the Musi basin by the coastal current flowing along the Bangka Strait from September to May.

The geologists did not neglect the Musi estuary. Off the eastern side of the estuary opposite Sungsang, the Admiralty's sailing directions locate payung Island and advise pilots to be aware of a bar between the southern end of Pulau Payung and the estuary's shore.43 Pulau Upang is the mud mass that separates the Musi estuary from the Upang estuary. The geologists investigated the natural history of both Pulau Payung and Pulau Upang, and their findings in these two places are significant. The nipa palm has taken over from the earlier mangrove trees, while burrowing crabs are playing a major role in raising

${ }^{39} \mathrm{~V}$. Obdeyn, "Zuid-Sumatra volgens de oudste berichten I-III " Tijdschrift Konink. Ned. Aard. Gen., 58 (1941), pp. 190-217, 332-43, 476-503; 59 (1942), pp. $46-76,742-71 ; 60$ (1943), pp. 102-11.

$40 \mathrm{~J}$. N. Miksic, "Archaeology and Palzeography in the Straits of Malacca," in Economic Exchange and Social Interaction in Southeast Asia: Perspectives from Prehistory, History, and Ethnogrophy, ed. Karl L. Hutterer, Michigan Papers on South and Southeast Asia, No. 13 (1977), p. 164.

${ }^{41}$ M. J. G. Chambers and A. Sobur, "The Rates and Processes of Recent Coastal Accretion in the Province of South Sumatra: A Preliminary Survey" (Paper presented at the Regional Conference of the Geology and Mineral Resources of South East Asia, Jakarta, 1975).

${ }^{42}$ The geologists note that in this part of the region facing Bangka not a single major river originates outside the swamp zone, and they infer that recent sediments must therefore derive from the sea rather than from the interior.

${ }^{43}$ Eastern Archipelago Pilot, p. 65. 


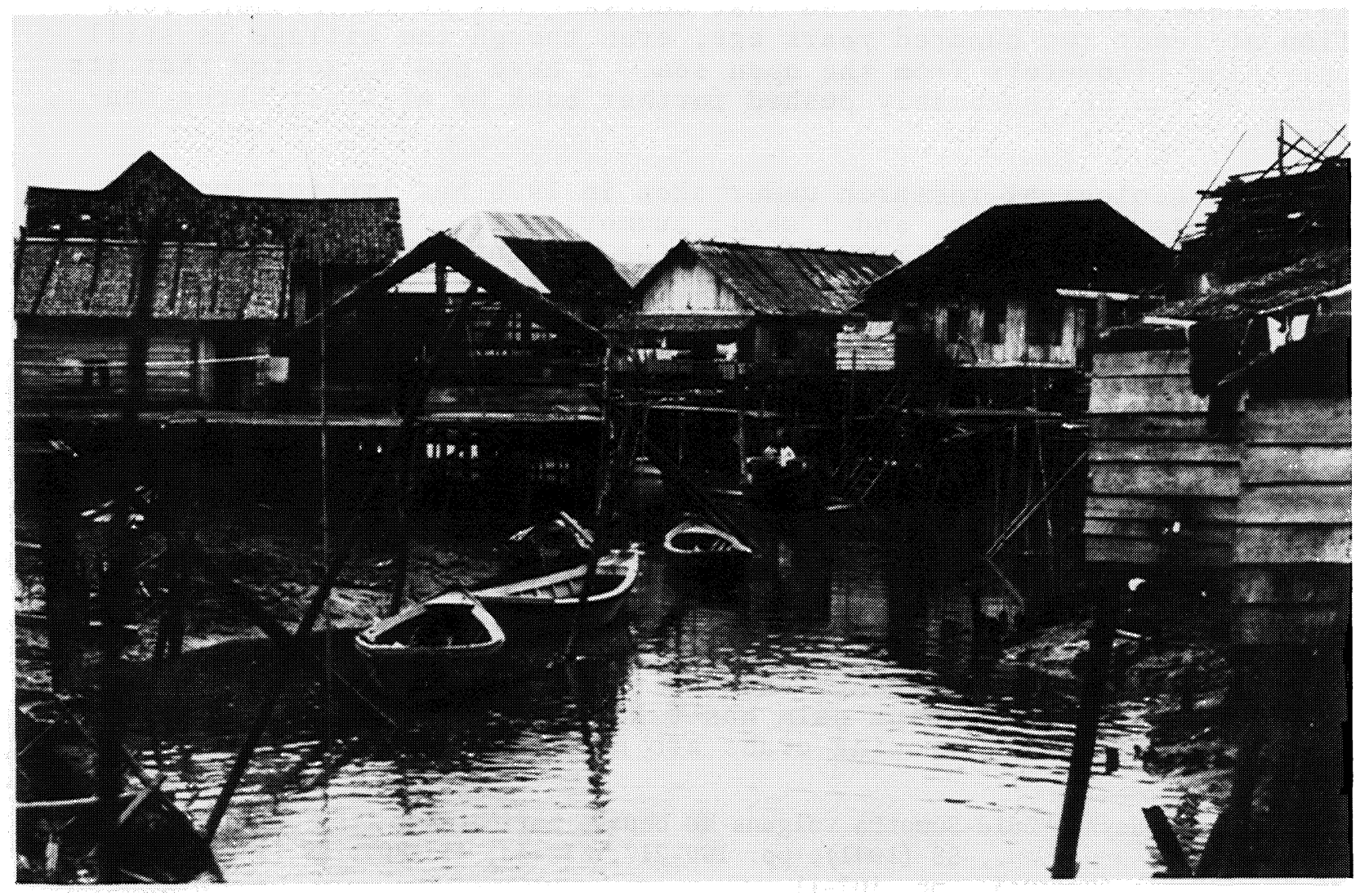

SUNGSANG (The Creek)

July 1978

Photo: Edwards E. McKinnon 
mounds of mud above tidal influence. 44 The geologists included in their survey a mud spit extending seaward from Tanjong Carat at the extreme northeastern tip of the coastal strip behind Sungsang village. There and along the northern shore they found that mangrove trees were only just beginning to establish themselves in the more recently deposited mud. They were protecting the shoreline from wave ernsion.

The mud pattern in the Musi estuary suggests that Sungsang village owes its long recorded history to the same sedimentation processes, activated by long-shore drift and seen at Tanjong Carat, but the site and environs of the village represent a much earlier phase of 1 and formation. The earlier phase is reflected in the fact that sungsang has already generated its own drainage system and fresh water supplies, for which the evidence is the tidal creeks in its immediate neighborhood. The village, because it partly faces inland and is sheltered by the estuary, does not suffer from wave erosion to the extent that Tanjong Carat does. 45

Bearing in mind these considerations, I suggest that by 1400 natural conditions existed for a settlement not far from the present site of Sungsang and visible from the estuary. Even if the terrain were not very stable at that time, an estuarine site would have been occupied because of its strategic importance. Fishermen could use it as a base for exploiting fishing grounds out to sea, and the rulers of the upriver state could use it as an observation post on the Bangka Strait.

Here, then, is a geological explanation for Sungsang's antiquity, attested to in the Chinese evidence reviewed above.46 I acknowledge, of course, the need for detailed geological survey, assisted by coring equipment and $C 14$ analyses of conchiolin from marine shells and of buried mangrove gathered from clays now distant from the sea, before the village's antiquity can be measured with anything approaching scientific precision. 47 Nevertheless, my present view is that a village can reasonably be supposed to have been in the neighborhood of present-day Sungsang during the fourteenth century.

The scene on the river banks during our rather swift voyage down and up the Musi between Palembang and Sungsang may also reflect the processes of mud history investigated by the geologists at Pulau Payung and Pulau Upang. When we were closer to the estuary, the Musi seemed to become narrower, its banks perceptibly higher, and the shoreline

${ }^{44}$ Nipa grows where mangrove once grew alone. Nipa depends on low salinity for growth, and its presence indicates a change from tidal to nearby freshwater swamp and therefore the progression of the coast away from this area. I am grateful to Dr. Miksic for discussing this aspect of the situation.

${ }^{45}$ According to de Sturler, atap work (possible owing to an abundance of nipa palm) was, with fishing, the means of livelihood at Sungsang in his day. De Sturler, Proeve eener Beschrijuing, p. 155.

${ }^{46} \mathrm{Dr}$. Miksic informs me that the presence of ancient Tertiary hills of laterite, causing a slight rise in the lower Musi valley, should be included among the geological factors responsible for the situation. found.

${ }^{47}$ For example, old beach ridges, now covered by river-borne deposits, may be 
vegetation more variegated.48 over the centuries river-borne rather than ocean-borne alluvium may have been banking up against the upstream sides of ocean-deposited mud masses to form always rising and expanding islands that were advancing from the sea shore towards Palembang. Several maps accompanying my earlier article give the impression that foreigners identified "islands" closer to the sea than to the city of Palembang. 49

The elevations along the Musi banks may once have been islands. Upang village, at the confluence of the Musi and Upang rivers and approximately half way between Palembang and Sungsang, is one example. This village may be a worthwhile site for establishing by geological investigation whether the site originally came into being as the result of long-shore drift or as a result of upriver alluvium. The chronology of Sungsang village, discussed above, supplies a control for reconstructing the history of the Upang mud. The results may throw light on changes in estuarine topography long before the fourteenth century. A visit to Upang may also disclose surface sherds and other signs of early settlement.

The scene near Palembang in earlier times probably resembled a large lake with numerous and ever growing islands. The landscape would have been dominated by the laterite peninsula behind the northern bank of the Musi. The memory of the islands is preserved today in the expression "Thousand Islands" (Pulau Seribu) to refer to the southern bank opposite Palembang city. 50 The search for ancient artifacts near Palembang has to take into account the location of 01 der mud deposits some distance behind the present shorelines of the river. As long ago as 1781 Radermacher remarked that not only was the Palembang coastline increasing "day by day" but that even above Palembang those who dug deep into the soil often found shells and pieces of vessels and prows. 51

I have now discussed the historical geography of Sungsang in the early fifteenth century. The topography would not have been significantly different in the fourteenth century. But the shun-fêng hsiangsung throws no light on the historical geography of the upriver port, known to Chinese merchants as the "01d Channel," and I shall therefore conclude with a few pieces of information from other sources about the upriver situation in the fourteenth century.

Wang Ta-yüan, in his account of the "O1d Channe1" settlement, drawn from Chinese merchants' observations in the first half of the fourteenth century, writes:

${ }^{48} \mathrm{I}$ would be interested in the results of botanical research along different reaches of the Musi shore below Palembang.

${ }^{49}$ To these maps should be added map $D$ facing page 211 of Obdeyn's article, "Zuid-Sumatra volgens de oudste berichten," Tijdschrift Konink. Ned. Aard. Gen., 58 (1941). The map was drawn in 1842 .

${ }^{50}$ The neighborhood of Palembang is still subject to inundation, and houses on stilts are the most familiar feature on the banks of the numerous creeks.

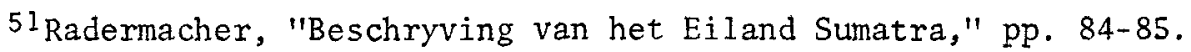


ESTUARIES OF THE BANYUASIN, MUSI AND UPANG RIVERS

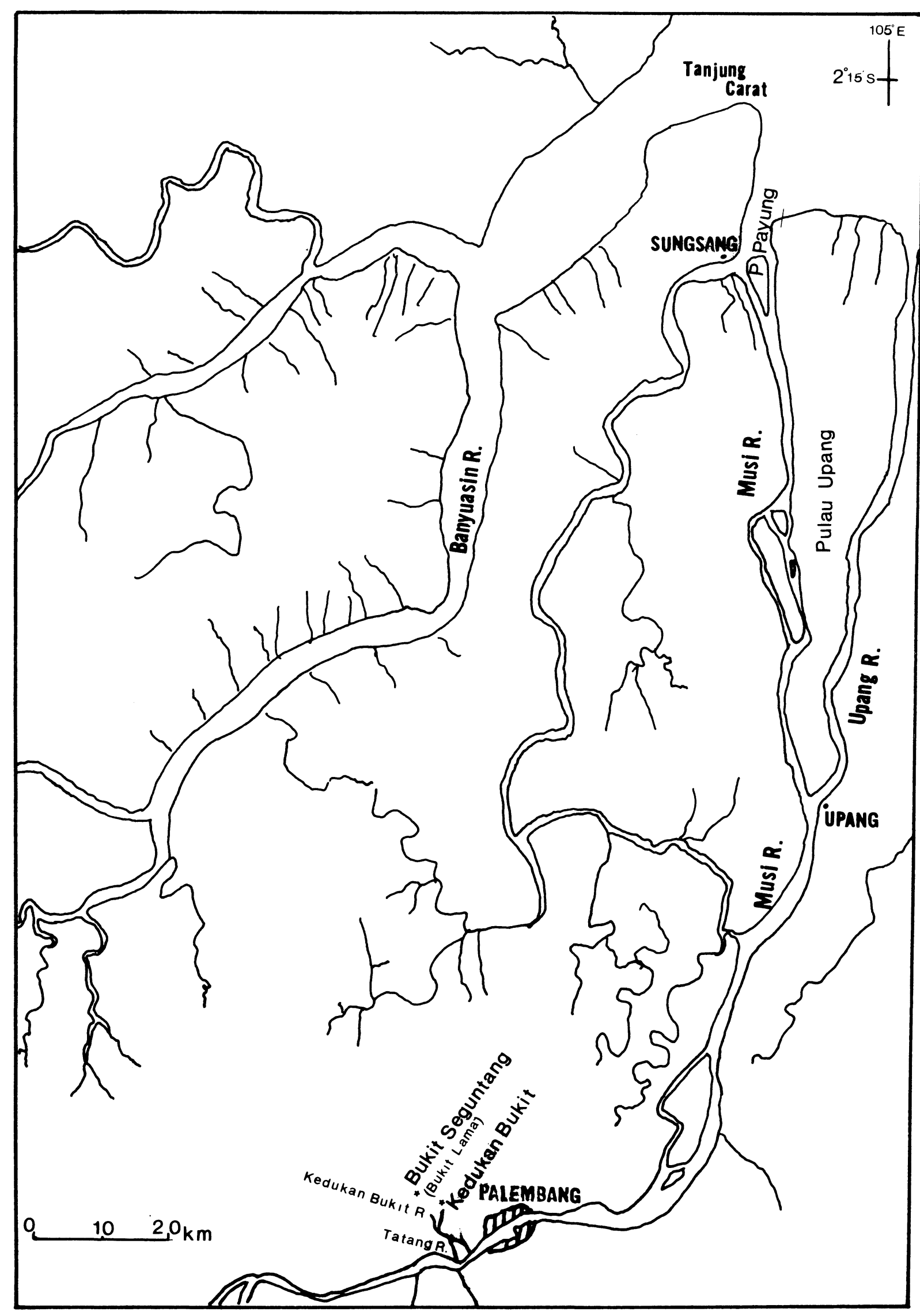


01d Channe1. One enters the Bangka Strait from a freshwater channel. The people use bamboo instead of ships. The roads have many brick stüpas. 52

The itinerary in question is from the Palembang area to the estuary. I now believe that, when Wang mentions the "freshwater channe1," he is referring to nothing other than the Musi itself near the modern city of Palembang, where the river water becomes less saline at low tide and where, according to his informants, the local inhabitants plied light craft or rafts. The brick stüpas were probably built on adjacent dry soil at the foot of the slopes of higher land behind the mudflats along the northern bank of the Musi, where roads could also be constructed. The higher land extends from behind the modern city to the slopes of Bukit Seguntang and Bukit Lama. I referred to this 1 and as a "peninsula" when I wrote my article on "Landfall on the Palembang coast in medieval times." 53

The fourteenth century was an important one in Palembang's history, and we have a glimpse of the settlement's location in a Malay as well as in a Chinese source. In the 1390 s the Majapahit ruler punished his palembang vassal for repudiating Javanese overlordship, attacked his capital, and laid it low. The Malay ruler escaped and eventually founded Malacca at the beginning of the fifteenth century. 54 Whether or not Sri Tri Buana, who, according to the Sejjarah Mézayu, miraculously descended on Bukit Seguntang a few miles west of Palembang city, represents the founder of Malacca, the description of Sri Tri Buana's capital in the Palembang area, where he first ruled, is worth noting: "its river was the Muara Tatang."55 Today the Sungei Tatang is a very small deltaic creek on the northern shore of the Musi a mile or so south of Bukit Seguntang and is connected to the Sungei Kedukan Bukit creek. The latter is in the vicinity of sites where various antiquities from Palembang's Buddhist past have accidentally come to 1 ight over the years, and it emerges close to the southeastern slopes of Bukit Seguntang. The Tatang's location, near the prestigious Bukit Seguntang, and its mention by the Sĕjarah Mĕlayu suggest that it was once an important stream, and this suspicion is strengthened when we note that Leidekker's manuscript gives "Tatoeng" as the name of the palembang river, known as the Mus $i$ only in its upper reaches. 56

${ }^{52}$ Wang Ta-yulan, Tao-i chih-lüeh chiao-chu, p. 84. W. W. Rockhill, "Notes on the Relations and Trade of China with the Eastern Archipelago and the Coast of the Indian Ocean during the Fourteenth Century, Part II," T'oung Pao, 16 (1915), p. 135. I have improved my translation since I rendered it in "Landfall," p. 9.

${ }^{53}$ The peninsula is indicated on map 12 on page 38 of the article.

${ }^{54}$ Wolters, Fall of Smivijaya, ch. 5.

${ }^{55} \mathrm{C}$. C. Brown, "Sĕjarah Mĕlayu or 'Malay Annals'. A Translation of Raffles MS 18," Joumal of the Malayan Branch of the Royal Asiatic Society, 25, 2-3 (1952), p. 24. For a seventh century 01d-Malay use of the word muara in the Palembang context, see J. G. de Casparis, Prasasti Indonesia II (Bandung: Masa Baru, 1956), p. 5: "they will be swallowed by the river (muara)." Wilkinson defines muara as "the broad tidal estuary of a Malayan river"; R. J. Wilkinson, A Malay-English Dictionary

(Singapore: Kelly and Walsh, 1903), p. 660.

${ }^{56}$ See Von de Wall, MaZeisch-NederZandsch Woordenboek, vo1. 1, p. 322, where Leidekker is cited. The word is spelled tat-ng. Marsden gives "tatang" or "tatong"; William Marsden, A Dictionary of the Malayan Language, in two parts (London: printed by Cox and Baylis for the author, 1812), part 1, p. 63 . 
Leidekker, author of the Maleisch-Holzandsch Woordenboek, came to the Indonesian archipelago in 1675.57

Thus, the Sĕjarah Mĕlayu's vision of the Bukit Seguntang area as a riverine site is consistent with the Chinese conception of the "Old Channel" in the fourteenth and fifteenth centuries as a port somewhere up the Musi. Another passage in the same text shows even more clearly that Bukit Seguntang was believed to be some distance from the sea. Sri Tri Buana, wanting to "inspect the sea" and found a new capital, headed out to sea with his fleet from "the Kuala Palembang," which is a name today for the Musi estuary at Sungsang. 58 The founder of Malacca would have taken the same route when he escaped from the Javanese about thirty years before the Mao $\mathrm{K}^{\prime}$ un map was drawn. When he reached Malacca, he chose an upriver location as the site of his residence. 59

In the fourteenth century Palembang's inland and riverine location would not have been very different from that of sixteenth century Aru. According to Tomé Pires, the Aru ruler "lives in the hinterland, and has many rivers in his country. The land in itself is marshy and cannot be penetrated."60 Yet this location did not prevent Aru from exercising influence among the orang laut on the coast and becoming an aggressive state in the Straits of Malacca.61

We know little of Palembang's maritime reach in the fourteenth century. We can suppose, however, that those who lived at the estuary at that time performed at least the same range of services as the Sungsang villagers, as they are described in Malay literary sources from Palembang, performed at the beginning of the nineteenth century, when they served as estuary guards, inspected merchant ships entering the Musi, and rowed upstream with urgent news.62 A copy of the agreement between the VOC and the Sultan of Palembang in 1681 was sent to the Company's servants at Sungsang to inform them that they were now allowed to visit incoming and outgoing ships, 63 and I suspect that the reason was to protect Dutch ships from the supervisory attentions of

${ }^{57}$ On Leidekker (1645-1701) see Encyclopaedie van Nederlandsch-Indië, 2nd ed. (The Hague: Nijhoff, 1918), 2, p. 564.

58 Brown, "Sĕjarah Mĕlayu," p. 28. At the beginning of the nineteenth century the estuary was known as the "Kuala Sungsang"; M. O. Woelders, Het SuZtanaat Palembang 1811-1825, Verhandelingen van het Koninklijk Instituut voor Taal-, Land- en Volkenkunde, 72 (The Hague, 1975), passim. I do not know when the expression "Kuala Sungsang" was first used. The compiler of this part of the Malay Annals lived on the Malay Peninsula and may not have been familiar with Palembang usage. According to the Eastem Archipelago Pilot, the Musi between Upang village and Sungsang village is known as the Sungsang river; Easterm Archipelago Pilot, p. 64.

${ }^{59} \mathrm{~A}$. Cortesão, trans. and ed., The Suma Oriental: An Account of East, from the Red Sea to Japan, Written in Malacea and India in 1512-1515, 2 vols., 2nd ed. (London: Hakluyt Society, 1944), 2, pp. 233-36, on Bietom or Bretao or Bretam, an upper tributary of the Malacca river. Also see Brown, "Sĕjarah Mĕlayu," pp. 51-52, on Bertam.

${ }^{60}$ Cortesão, Suma Oriental, 1, p. 147. ${ }^{61}$ Ibid., pp. 147-48.

62 Woelders, Het Suztanaat Palembang 1811-1825, passim.

${ }^{6}{ }^{3}$ Dagh-Register for the year 1681, p. 485. 
the Sungsang estuary guards. The final clause of the agreement of 1755 was intended to protect Dutch merchants from molestation by the inhabitants of Sungsang. 64

Our visit to Sungsang enabled us to interpret details on the Mao K'un map that delineate the topography of the Musi estuary. Our conclusion is that nearly eight centuries ago the city of Palembang was as far from the Bangka Strait as it is today, though the fairway probably resembled an inland gulf, sprinkled with islands. Historians of palembang, influenced by obdeyn's pioneering reconstruction of the ancient Sumatran map, may tend to assume that the palembang coastline has changed beyond recognition during the last fifteen hundred years. I certainly did when I wrote my article in 1975. My present view is that major geomorphic changes, affecting Palembang's access to the Bangka Strait, did not happen in historical times. Instead, the estuary's appearance altered when what were once small islands of mud, deposited by long-shore drift, gradually combined to form larger islands in a narrowing channel, while the appearance of the lower Musi basin altered as the result of alluvium deposits that adhered to the riverine shorelines. I suggest that no geographical changes before the fourteenth century require more exact scrutiny than those in the Palembang area itself and especially in what is today the creekland in the neighborhood of Bukit Seguntang and Bukit Lama, where antiquities of Sriwijaya have already been recovered with only the minimum of research. A detailed geological survey of the Bukit Seguntang terrain will assist archaeologists in distinguishing more recent deposits of riverine alluvium behind the present estuaries of such creeks as the Sungei Tatang from terrain that existed during Sriwijaya's heyday from the seventh to the eleventh century.

64"Het contract van 1755 met Palembang (uit het Rijksarchief)," Tijdschrift voor Nederlandsch Indie, 4th series, 9, 2 (1880), p. 184. 